\title{
How Does COVID-19 Affect the Neurobiology of Suicide?
}

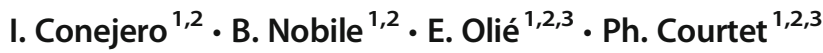 \\ Accepted: 21 January 2021 / Published online: 3 March 2021 \\ (C) The Author(s), under exclusive licence to Springer Science+Business Media, LLC part of Springer Nature 2021
}

\begin{abstract}
Purpose of Review The aim of this review was to analyze COVID-19 effect on the biological features of suicidal vulnerability and its interaction with suicide-related biological pathways. We carried out a narrative review of international publications on the interactions of COVID-19 with the biological bases of suicide.

Recent Findings We hypothesize that SARS-CoV-2 interacts with multiple biological processes that underlie suicidal behavior, such as the renin-angiotensin system, nicotinic receptors, and central and systemic inflammation. Social distancing measures may also worsen subjective or objective social disconnection, thus increasing the risk of suicide. Interestingly, the drugs used to prevent suicide could be promising options to counteract brain damage caused by this coronavirus.

Summary SARS-CoV-2 interacts with multiple biological pathways involved in suicide and opens a new window for understanding the suicidal process. The development of suicide prevention treatments in the context of a pandemic may benefit from knowledge on these interactions.
\end{abstract}

Keywords COVID-19 $\cdot$ Suicidal vulnerability $\cdot$ Inflammation $\cdot$ HPA axis $\cdot$ Social isolation $\cdot$ Psychotropic treatments

\section{Introduction}

The first human cases of infection by the novel severe acute respiratory syndrome-coronavirus type 2 (SARS-CoV-2) were identified in the city of Wuhan, China, at the end of 2019. Today, with more than $100,000,000$ individuals diagnosed worldwide [1], the COVID-19 outbreak has reached a large part of the world population.

Besides the respiratory symptoms, the pandemic might have an emotional impact and might favor the emergence or worsening of psychiatric symptoms in people with COVID19 or with a specific vulnerability to mental disorders [2]. Indeed, during the previous SARS pandemic, people developed psychological symptoms due to the quarantine, or

This article is part of the Topical collection on Mood Disorders

I. Conejero

ismael.conejero@gmail.com

1 Department of Emergency Psychiatry and Acute Care, Lapeyronie Hospital, CHU Montpellier, Montpellier, France

2 PSNREC, Univ Montpellier, INSERM, CHU de Montpellier, Montpellier, France

3 FondaMental Foundation, Créteil, France psychological stress linked to the fear of contamination. For instance, in Canada, a significant proportion of the 1057 individuals confined during the SARS epidemic reported fear symptoms (20\%), sadness (18\%), and even feeling of guilt (10\%) [3]. Some of these symptoms persisted after 3 years of follow-up: substance use, alcohol dependence, or posttraumatic stress disorder [4]. During the current pandemic, more than $29 \%$ of patients with COVID-19 developed depressive symptoms in the province of Guangdong [5]. Moreover, around $20 \%$ of patients with a pre-existing psychiatric disorder reported worsening of their psychological state and interruption of psychiatric care during the pandemic [6]. The negative psychological impact was severe in psychiatric patients, particularly for anger, impulsivity, and suicidal ideation [7]. It was also suggested that young-old people may be at risk of increased depressive symptoms and suicidal acts [8].

The psychosocial stress imposed by the society changes in response to this pandemic may increase the vulnerability to suicidal behaviors at several levels. Social isolation, resulting from the quarantine imposed to more than a half of the world population, is a well-known risk factor for suicide [9]. Quarantine may worsen the risk of domestic violence and limit the possibilities of psychological support [10]. The announced economic crisis also is likely to influence suicide rates [11]. It has been estimated that the related rise of unemployment will lead to more suicides (up to 9570 additional 
suicides per year) [12]. Therefore, an increase of suicide rates, as observed during the Spanish "flu" pandemic (1918), is expected [13]. Consequently, the present pandemic is a source of concern in populations facing psychosocial stressors. In many vulnerable people, the emotional, social, health, and financial consequences of this pandemic could lead to mental health problems and suicidal behaviors, in the immediate aftermath and also in the longer term. The scientific and mental health communities should proactively prepare and use this challenging period to improve suicide research and prevention.

Recent biological data suggest that SARS-CoV-2 can affect the central nervous system (CNS) [14] through biological pathways implicated in suicidal behaviors: renin-angiotensin system, inflammation system, and nicotine receptors. Social distancing measures also are leading to neurobiological changes involved in suicidal behavior, such as inflammation [15]. A better understanding of the connections between COVID-19 pathophysiology and the biology of suicide is the first step to address suicide prevention and to propose effective treatments in a pandemic context.

In this review, we propose to highlight the possible biological mechanisms through which COVID-19 may influence suicidal vulnerability and increase the risk of suicidal acts. A better understanding of this link may help to identify the populations at risk and to monitor patients with the highest suicidal risk in an adequate time window, depending on the midand long-term neuropsychiatric consequences. We also discuss how the COVID-19 outbreak may help to better understand the neural and biological correlates of suicidal behavior. Finally, we focus on interactions between the psychotropic medications used to treat suicidal patients and COVID-19 and discuss how these drugs might limit the inflammation induced by SARS-CoV-2.

\section{Viral Infection: Is there a Link with Suicidal Acts?}

Studies on respiratory viral infections have identified an association between infection and risk for suicide. Specifically, mood disorders have been associated with the presence of antibodies against influenza $\mathrm{A}$ and $\mathrm{B}$ viruses and a coronavirus strain (HCov-NL63) [16]. Influenza B seropositivity has been significantly associated with history of suicide attempt $(\mathrm{OR}=2.53$, CI 1.33-4.80). In general, exposure to infectious agents is an aggravating factor for the risk of self-harm [17]. This study, based on the analysis of Danish registers, showed that individuals with infections are at greater risk of deliberate self-harm compared with controls (hazard rate ratio: 1.80 $(95 \% \mathrm{CI}=1.68-1.91))$. Redeemed prescriptions for antiinfective medications were considered as a proxy for infection. In addition, this association depended on the infection severity, as indicated by the higher suicide risk in individuals hospitalized for infections (hazard rate ratio: 3.13 (95\% CI =
1.67-5.87)) [17]. The underlying causes are multiple, including inflammatory changes [18], and microbiota modification secondary to the use of anti-infective agents and its influence on the CNS [19••]. Several mechanisms might be at work in the infection-related brain damage: retrograde axonal transport of the virus from the respiratory mucosa [14], peripheral inflammation that modulates brain function, and migration of mononuclear cells transporting the virus across the bloodbrain barrier (BBB) [14]. Finally, some studies suggested that antiviral agents also could influence mood disorders, as summarized in Table 1.

Suicide attempts, completed suicides, and respiratory viruses share seasonal patterns. Human coronaviruses, respiratory syncytial virus, and influenza virus have a peak incidence during the winter months [20], immediately followed by suicide (especially violent suicide), the incidence of which is maximal in spring and early summer [21]. Only some types of respiratory enteroviruses have a peak overlapping with suicide [20]. Although a link between the annual fluctuations of suicidal acts and infections has not been demonstrated yet, they might share some determinants that follow seasonal patterns, such as the host immune characteristics. Maes et al. (1996) showed that the violent suicide peak is synchronized with variations of the $\mathrm{CD} 4+/ \mathrm{CD} 8+$ cell ratio [22] and number of CD20+ B cells that are involved in viral immunity [23, 24]. Interestingly, CD4+ and CD8+ cell concentrations are decreased in patients with COVID-19 [25]. Finally, chronic low-grade inflammation induced by infection may increase suicide risk in the months after the viral peak incidence [26]. Therefore, in the period following the pandemic peak, the populations at risk should be closely monitored due to the effect of seasonal cyclicity, chronic immune response, and delayed neuropsychiatric sequelae [14].

\section{COVID-19 and the Renin-Angiotensin System: A Path to Suicide}

The most recent research on COVID-19 has shown that the virus enters host cells through interaction of its spike protein with the angiotensin-converting enzyme 2 (ACE-2) receptor that is expressed at the cell surface $[27,28,29]$. ACE-2 is broadly expressed in human cells, including gastrointestinal, heart, and alveolar cells [30], and CNS [31]. Consequently, concern has been raised on the use of angiotensin-converting enzyme inhibitors (ACEIs) and angiotensin receptor blockers (ARBs) because they might increase ACE-2 expression, particularly in the cardiovascular system and CNS [31, 32], and facilitate SARS-CoV-2 entry [30, 33].

Interestingly, previous studies established the implication of the renin-angiotensin system in suicidal vulnerability, particularly the use of ARB. In a study in which 964 people who died by suicide were matched with 3856 controls, the risk of suicide death was higher in ARB users than in ACEI users 
Table 1 Main treatments tested in ongoing trials in patients with COVID-19 for which there are data on mood disorders and suicide risk [156, 157]

\begin{tabular}{|c|c|c|c|}
\hline Treatment & Type & Mechanism of action & Effect on mood disorder and suicide risk \\
\hline Chloroquine & Antimalarial & $\begin{array}{l}\text { Endosomal acidification, fusion inhibitor, } \\
\text { anti-inflammatory activity }\end{array}$ & $\begin{array}{l}\text { No direct effect on suicide, but increased risk of } \\
\text { depression [158] }\end{array}$ \\
\hline Hydroxychloroquine & Antimalarial & $\begin{array}{l}\text { Endosomal acidification, fusion inhibitor, } \\
\text { anti-inflammatory activity }\end{array}$ & Increased risk of depression and suicidal ideation [159] \\
\hline Lopinavir & Antiviral & Protease inhibitor & $\begin{array}{l}\text { Inconclusive data, but effects on mood disorders } \\
{[160-163]}\end{array}$ \\
\hline Ritonavir & Antiviral & Protease inhibitor & $\begin{array}{l}\text { Inconclusive data, but effects on mood disorders } \\
{[160-163]}\end{array}$ \\
\hline Oseltamivir & Antiviral & Potent and selective inhibitor of neuraminidase & $\begin{array}{l}\text { Inconclusive data, but possible effects on mood } \\
\text { disorders [164-166] }\end{array}$ \\
\hline Interferons & Antiviral & $\begin{array}{l}\text { Inhibition of viral RNA transcription, protein } \\
\text { translation, and post-translational modification: } \\
\text { suppress virus replication }\end{array}$ & $\begin{array}{l}\text { Significant increased risk of depression, suicidal } \\
\text { behavior }[167,168]\end{array}$ \\
\hline Tocilizumab & $\mathrm{mAb}$ & Humanized mAb against IL-6 & $\begin{array}{l}\text { Significant improvement of depressive symptomatology } \\
\text { (from randomized controlled trials in depressed } \\
\text { patients) }[169-171]\end{array}$ \\
\hline Sarilumab & $\mathrm{mAb}$ & Humanized mAb against IL-6 & $\begin{array}{l}\text { Significant improvement of depressive symptomatology } \\
\text { (from randomized controlled trials in depressed } \\
\text { patients) [169-171] }\end{array}$ \\
\hline Anakinra & $\mathrm{mAb}$ & Human IL-1 receptor antagonist & Possible positive effect on depression [172] \\
\hline Adalimumab & $\mathrm{mAb}$ & Humanized $\mathrm{mAb}$ against $\mathrm{TNF} \alpha$ & $\begin{array}{l}\text { Significant improvement of depressive symptomatology } \\
\text { (from randomized controlled trials in depressed } \\
\text { patients) [169-171] }\end{array}$ \\
\hline Corticosteroids & Corticosteroids & Dampen pro-inflammatory cytokines & $\begin{array}{l}\text { Increased risk of mood disorders and possibly of } \\
\text { suicidal behavior [173-175] }\end{array}$ \\
\hline
\end{tabular}

(OR: $1.63 ; 95 \% \mathrm{CI}, 1.33-2.00)[34,35]$. Furthermore, the presence of the ACE insertion/deletion (I/D) polymorphism has been associated with suicidal behavior in two independent case-control studies $[36,37]$. Specifically, the ACE D/D genotype was associated with higher suicide risk (OR: 2.4, 95\% CI 1.2-4.8 and OR: 1.3, 95\% CI 1.0-1.7, in each cohort). D allele carriers have higher ACE serum levels than I allele carriers [38]. Another study reported the association between this $A C E$ polymorphism and suicidal behavior in Japanese males [36]. Similarly, Baghai et al. found an association between the single nucleotide polymorphism rs4291 in $A C E$ promoter region and unipolar depression in two independent case-control samples that included, in total, 843 unrelated patients with unipolar depression and 1479 healthy controls [39]. In addition, the higher plasma concentrations of ACE linked to the presence of the $\mathrm{D} / \mathrm{D}$ genotype promote the hypothalamic-pituitary-adrenal (HPA) axis activity in depressed individuals [40]. The D/D genotype has been associated also with bipolar disorders and psychotic symptoms in bipolar patients [41], all risk factors for suicide. $A C E$ genetic variants have been detected in older people who meet criteria for depressive disorder and were associated with higher cortisol secretion [42].

Although SARS-CoV-2 targets the ACE-2 receptor, both homologous enzymes (ACE and ACE-2) act in brain cells through a shared enzymatic cascade (angiotensin II is produced by ACE and is an ACE-2 substrate), intracellular gene regulation, and nitric oxide release [31]. SARS-CoV-2 has neuro-invasive potential [43] and could enter the CNS by targeting the ACE-2 receptors that are widely expressed in the brain and BBB [44]. The virus decreases ACE-2 activity [45], and this might unbalance ACE/ACE-2 metabolic pathways. This could affect the vulnerability to suicide in individuals who carry the "risky" $A C E$ genotypes. Moreover, ACE-2 downregulation by SARS-CoV-2 might interfere with monoamine synthesis in the brain, for instance, dopamine [46], that is implicated in mood disorders and suicidal behaviors. Hence, the hypothesis that SARS-CoV-2 infection might increase suicidal vulnerability through the renin-angiotensin system should be explored in future studies.

Interestingly, a recent review suggests that nicotine might interfere with the renin-angiotensin system [47].

\section{SARS-CoV-2 Targets the Nicotine Receptor: What About Suicide in Smokers?}

A large body of evidence supports the existence of strong relationships between tobacco consumption and suicidal behaviors. In a study on 347 psychiatric patients, smokers were more likely to attempt suicide (OR: $2.60,95 \%$ CI $1.60-4.23$ ) 
compared with non-smokers, even after adjustment for sociodemographic and clinical data [48]. A meta-analysis reported that current smokers are at greater risk of suicidal ideation, plans, attempts, and completed suicide [49]. This association could be explained by an impairment of serotonin function by smoking [50]. The link between nicotine intake and monoamine dysfunction is suggested by the pre-synaptic localization of nicotinic cholinergic receptors on catecholamine and serotonin axons [51]. Furthermore, nicotine administration in murine models decreases serotoninergic transmission in the hippocampus and reduces firing of serotoninergic neurons in the midbrain [48, 52]. In parallel to its direct effect on suicide, the acetylcholine system is closely related to depression that in turn increases the vulnerability to suicidal acts and might be deregulated by alterations in nicotinic acetylcholine receptor signaling [53].

Recent reports showed that the nicotinic cholinergic system is dysregulated in patients with COVID-19 [54], and tobacco exposure has been associated with disease progression [55]. In addition, structural studies suggest that SARS-CoV-2 might enter the CNS by binding to nicotinic receptors [56]. According to the "nicotinic hypothesis," SARS-CoV-2 spike protein contains a motif that is homologous to the neurotoxinlike region that is found in the rabies virus that acts as nicotinic acetylcholine receptor blocker. Hence, through its interaction with the cholinergic system, SARS-CoV-2 might interfere again with suicidal vulnerability.

ACE-2 expression in bronchial epithelial cells is higher in smokers than non-smokers [57]. Moreover, nicotine upregulates $\mathrm{ACE}$ and its subsequent metabolic cascade in the CNS and downregulates ACE-2, further unbalancing the brain renin-angiotensin system $[58,59]$. In addition, nicotinic receptors contribute to the pathophysiology of inflammation and modulate the inflammatory response, including the secretion of tumor necrosis factor $\alpha$ (TNF $\alpha$ ), interleukin-1 (IL-1), and interleukin-6 (IL-6) [60] that have been associated with depressive phenotypes [61] and suicidal vulnerability [62]. Altogether, the interconnexions of these different pathways show that nicotinic receptors may participate in the association between COVID-19 and suicidal behavior. However, this relationship may be modulated by a specific infection profile in smokers that has to be determined.

\section{SARS-CoV-2, Inflammation, and HPA Axis: A Pathway Shared with Suicide}

Following the viral invasion phase, SARS-CoV-2 induces a cytokine "storm" in a subgroup of patients that dramatically worsen their clinical outcome [63]. This is accompanied by the release of the pro-inflammatory cytokines IL-6, TNF $\alpha$, and IL-1 [63, 64]. Cytokine release syndrome leads also to an increase of the serum levels of cytokines, C-reactive protein (CRP), and IL-2 receptor and a decrease of the CD4+/
CD8+ ratio [25, 65]. COVID-19-related inflammation may also extend to the CNS through BBB breakdown, viral neuro-invasion, and cytokine secretion [66]. In the brain, SARS-CoV-2 infection can initiate chronic low-grade inflammation that alters cognitive functions and induces neurotoxicity and neurodegeneration [26], thus preparing the ground for psychiatric disorders.

Studies have reported an association between baseline blood level of cytokines and brain activation in psychiatric populations. For example, the basal level of peripheral IL-1 and IL-2 modulates the activation of cerebral networks dedicated to emotion regulation (anterior cingulate, orbitofrontal cortex, and insula) [67] in patients with history of depression. In line with the link between peripheral inflammatory markers and emotion processing, several studies have established an association between basal low-grade systemic inflammation and suicidal behaviors [68]. Indeed, CRP blood level has been associated with suicide attempts [69] and with the intensity of suicidal ideation [70]. Two meta-analyses reported increased concentration of IL- $1 \beta$ and IL- 6 in the blood and in the brain samples from people who died by suicide [71] and reduced IL-2 plasma levels in suicidal patients [18].

Interestingly, IL-6 plays a key role in SARS-CoV-2-related inflammation [65], particularly patients with severe COVID19 [72]. IL-6 has been linked to psychological dimensions that underlie the suicidal process (e.g., impulsivity and the choice of violent suicide attempt method) [73] and may cause depressive disorders [74]. Moreover, IL-2 receptor increase has been related to COVID-19 [25] and vulnerability to suicide [75].

Some studies have highlighted the implication of monocytes in SARS-CoV infection as host cells for viral replication [76], and through the regulation of immune-related genes, and induction of monocyte-associated immune response [77] that may be a starting point for the inflammatory storm. Monocytes are implicated also in the pathogenesis of psychiatric disorders and suicidal behaviors. Indeed, monocyte trafficking within the CNS increases in stress conditions, provides information on the peripheral immune state, and amplifies the behavioral stress response [78]. Monocyte trafficking also activates microglia, and microglial hyperactivation, especially in the anterior cingulate cortex and insula, has been detected in patients with suicidal thoughts [79••]. Microglial activation is also induced by peripheral inflammation first within the circumventricular organs, leptomeninges, and choroid plexus and then throughout the CNS [78]. Interestingly, the monocyte-to-lymphocyte ratio in peripheral blood samples has been associated with age at first suicide attempt [80], and activated monocytes are more likely to be detected in plasma from patients with depression [81]. Higher monocyte count and increased IL-6 level were observed in patients at risk for suicide [82].

Importantly, it has been proposed that the rapid action of ketamine (NMDA antagonist) significantly reduces 
depression and suicidal ideation through the decrease of proinflammatory cytokines [83]. Its antidepressant effect partially relies on modulation of the immune response: reduction of circulating classical pro-inflammatory monocytes and increase of alternative M2 macrophages [81]. Finally, some anti-inflammatory agents (such as anti-IL6 antibodies) that are currently tested in COVID-19 have shown efficacy in individuals with mood disorders (Table 1). These findings suggest that SARS-CoV-2 infection may potentially impair the brain immune system underlying the suicidal process.

In addition, SARS-CoV-2 infection and suicidal risk are associated with modifications of the HPA axis function. Reports on previous coronavirus outbreaks have highlighted a possible interaction between coronaviruses and cortisol secretion [84]. Indeed, SARS-CoV (a coronavirus that shares high similarities with SARS-CoV-2) expresses sequences that mimic the host adrenocorticotropic hormone (ACTH). This results in the fixation of host antibodies on ACTH and blunting of cortisol secretion [85]. Moreover, SARS-CoV might also cause hypophysis dysfunction, resulting in HPA axis under-activation and hypocortisolism, which was observed in 39\% of SARS-CoV survivors [86]. Although there is no direct evidence of impaired cortisol secretion in patients with COVID-19, HPA axis dysfunction is a potential consequence of this viral disease that might affect suicidal vulnerability. Indeed, blunted cortisol secretion is observed in patients with depression and lifetime history of suicide attempts [87]. Moreover, decreased cortisol secretion may precede a suicidal act [88]. The dexamethasone suppression profile may help to predict the most lethal suicidal acts during a 2-year follow-up [89]. Finally, patients at risk of suicide may show higher susceptibility to HPA dysregulation following SARS-CoV-2 infection because the virus targets the ACE- 2 and the ACE/ ACE-2 balance that is associated with HPA dysregulation in depressed individuals [40, 42].

\section{Social Distancing and Vulnerability to Suicide}

Human beings are social creatures: people survive and thrive by connecting with others. Currently, people around the globe have been urged to self-isolate and refrain from social interactions due to the COVID-19 pandemic. The risk of suicide may also be increased by the social consequences of the pandemic and the related lockdown: loneliness and social isolation, stigmatization and social rejection, and increase of interpersonal difficulties (e.g., domestic violence). Reynolds et al. found that loneliness was reported by $38.5 \%$ (95\% CI $35.5-$ 41.5 ) and social isolation by $60.6 \%$ (95\% CI 57.6-63.6) of individuals $(n=1057)$ quarantined during the 2003 SARS outbreak in Canada [3]. Moreover, SARS-related studies revealed that $9.7 \%$ to $48.7 \%$ of people experienced stigmatization, abandonment, and isolation. A study on Ebola survivors showed that stigmatization concerned not only survivors or people related to a survivor [90] but also people of a specific nationality or place of residency. Recently, the WHO warned that since the COVID-19 outbreak, Chinese are victims of xenophobia and social stigmatization, with immense levels of threats online and during public interactions.

Feelings of isolation arise as a result of being quarantined [90]. Social isolation exacerbates personal and collective vulnerabilities, while limiting the accessible and familiar support options [10]. A recent review by Calati et al. (2019) suggests that social isolation (i.e., objective physical separation from other people) and loneliness (i.e., subjective distressed feeling of being alone or separated) are strongly associated with suicidal outcomes [9]. Being alone and negative family events increase suicidal ideation in recent suicide attempters. Feeling socially isolated or rejected leads to hypersensitivity to social threats [91] and increases negative relationships. At the biological level, loneliness and situations of social exclusion have been associated with increased HPA activity [91] and inflammation [92], two pathways related to suicidality $[18,71,88]$. Lonely individuals show stronger activation of the ventral striatum to pleasant pictures of objects compared with equally pleasant pictures of people, whereas the opposite is observed in non-lonely subjects. A functional circuit involving the striatal-anterior cortical midline structure plays a role in the expression of depressive symptoms and suicidal ideation [93]. In addition, loneliness has a mediating effect on the relation between the dorsolateral prefrontal cortex volume and attitudes toward suicide [94]. The regional gray matter volume of the left dorsolateral prefrontal cortex, a region involved in suicidal vulnerability, is higher in lonely individuals [95]. A review [96] on 28 fMRI studies during the Cyberball Game, a validated paradigm to study social exclusion, found several cerebral regions involved in exclusion: insula (anterior and posterior), prefrontal cortex, cingulate cortex (anterior and posterior), and temporal lobe. Dysregulation of insula and supramarginal gyrus during the exclusion versus the inclusion condition has been associated with suicidal vulnerability [97••]. These cerebral changes may affect emotional regulation, executive functions, and social cognition.

Since the COVID-19 outbreak, an increase in calls to domestic violence services has been observed in many countries [98]. It suggests an intensification of interpersonal conflicts, romantic difficulties, and child maltreatment. Indeed, the forced proximity changes the content of social interactions and may undermine the psychological resources, thus increasing the risk of aggression and domestic violence [99]. Interpersonal conflicts and affective difficulties might strongly increase the risk of suicidal acts, independently of psychiatric disorders [100]. Interestingly, affective difficulties have been associated with poor decision-making, a putative endophenotype of suicide [101]. Moreover, early exposure to maltreatment during childhood has been associated with a 3 -fold higher risk of suicide attempts in adulthood [102]. 
Maltreatment might alter neurobiological pathways, thus decreasing the ability to cope with demands from others and increasing vulnerability to future stressors. This might enhance the risk of emergence of psychiatric disorders, including suicide [103, 104].

\section{Preventing Suicide: At the Crossroad of Social Cohesion and Psycho-neuroimmunity}

Although other recent crises have been associated with a decrease in suicidal rate due to greater social cohesion [105] related to the proximity of life-threatening events [106], it is important to anticipate the potential deleterious psychological effects of COVID-19-related social distancing and social isolation. Several types of interventions have been proposed to reduce social distress, which is associated with suicidal ideation and acts [107] and predicts suicidal behaviors at 1 year [108].

The first strategy is to target the immune response that is induced by social distress [109] and that drives the emergence of depressive symptoms and increases the risk of suicide attempts $[62,110 \bullet \cdot$. Treatments with drugs that have also antiinflammatory properties, such as ketamine, show anti-suicidal effect immediately after their intake and for at least 1 week, independently of their anti-depressant effect [111]. Other pharmacological compounds, such as opioid molecules, modulate the activation of neural networks related to social interactions and lower the sensibility to social rejection [112] and social threats [113]. Moreover, low-dose buprenorphine efficiently reduces suicidal ideation [114••].

If future studies show that pro-inflammatory cytokines are increased in psychiatric patients during lockdown, more research will be required to evaluate pharmacological and nonpharmacological interventions (e.g., physical activity) to reduce the consequences of inflammation on health [115]. As soon as quarantine measures were put in place in many countries, the wording "social distancing" appeared. As this might aggravate feelings of loneliness and produce negative longterm health consequences, many authors requested to talk about "physical distancing," while promoting social connection [116]. Indeed, social connections help people to regulate emotions, cope with stress, and remain resilient during difficult times [117]. In these peculiar times, online interactions can help to foster a sense of connection and potentially boost psychological well-being [118]. Social connections are at the root of collective efficacy and foster hopefulness, as well as opportunities to witness and share positive emotions, compassion for others, altruism, and gratitude. Indeed, all forms of psychological support promote psychological resilience and enhance the psycho-neuroimmunity against COVID-19 [119]. As a matter of fact, self-compassion may protect against stress-induced inflammation and inflammation-related diseases [120]. Expression of gratitude, which is a very straightforward intervention for suicidal patients [121], moderates the relationships between stressful life events and IL-6 [122].

In their timely review on the psychological impact of quarantine, Brooks et al. (2020) highlighted that in order to reduce the mental health effect and to promote adherence, health authorities should emphasize the population's sense of altruism by stressing that their "staying at home" helps to keep others safe [123••]. Encouraging a shared sense of identity or purpose by acting for the common good may promote cooperative behaviors and increase shared social values (e.g., social cohesion). Social cohesion is a positive neighborhood characteristic defined by feelings of connectedness and solidarity within a community. Among many important personand neighborhood-level characteristics, social cohesion has been inversely correlated with psychological distress and with lower IL-6 levels [124].

Psychiatrists should educate and promote methods and interventions that foster positive behavioral changes and solidarity. Encouraging people to develop empathy and cooperation while fighting the COVID-19 pandemic may contribute to building compassionate societies and empathic civilizations [125]. Social support could limit the detrimental effects of social isolation on the immune system and may help to boost the psycho-neuroimmunity against this viral infection [119]. Concomitantly, the feeling of social safety and caregiving activates reward neural networks and modulates the expression of pro-inflammatory genes [126]. Social support also helps to prevent feelings of social disconnection and suicide. Algorithms that combine brief contact interventions have been tested [127] as well as connected technologies to prevent suicide in vulnerable patients $[128,129]$. A controlled study showed that acceptance and commitment therapy reduces suicidal ideation and psychological pain in high-risk patients with depression [107] and seems to have anti-inflammatory effects [130]. Engagement in art provides some forms of social support to isolated people and may increase the sense of belonging as well as protect from suicidal ideation [131]. In parallel to social connection, art also reduces cytokine levels in serum, such as IL-6 [132]. Encouraging people to share emotional experiences and to get social support should be one of the priority actions of the medical community [133]. Local organization should also help people to connect together, while adhering to physical distancing, in order to develop the sense of belongingness and of purpose [134].

\section{COVID-19 and Psychotropic Treatments}

Antidepressants (e.g., fluoxetine) reduce pro-inflammatory cytokines by attenuating the behavioral and neuroendocrine effects of immune activation [135]. Additional research is required to study the usefulness of antidepressants as part of the 
anti-inflammatory strategies against COVID-19 by reducing depression and somatic symptoms.

Actually, there is no specific treatment for suicidal behavior, although antidepressants, lithium, and clozapine are commonly used [136, 137]. It would be important to assess whether these psychotropic drugs interact and worsen infection by SARS-CoV-2 and whether the virus influences their metabolism. Patients taking these drugs often have comorbidities (e.g., diabetes) that increase the infection severity. Some of these treatments have side effects (e.g., neutropenia, dyspnea) that could worsen viral infection. On the other hand, the SARS-CoV-2-related inflammation might affect the metabolism of these drugs by acting on cytochromes [138]. This might increase or decrease the plasmatic levels of psychotropic drugs, thus leading to the appearance of side effects, or to a reduction of the drug efficiency, respectively. Finally, molecules tested in clinical trials on COVID-19 (e.g., hydroxychloroquine) could also interact with psychotropic medications and mutually potentiate their side effects (e.g., cardiac side effects) [139]. Currently, there is no international consensus on the use of psychotropic drugs during this pandemic, except for clozapine [140]. However, even if an interaction between SARS-CoV-2 and psychotropic drugs may exist, it is strongly recommended to continue taking the psychotropic medications [138, 139]. Indeed, discontinuation will engender serious deleterious effects for the patients. Indeed, a brutal interruption of lithium, antidepressants, or clozapine can increase the risk of suicidal behavior [141]. Therefore, it is important and necessary to continue treatments in patients at suicide risk and to closely monitor them (e.g., regular dosage of the drug plasma levels, appearance of COVID-19 symptoms) $[139,140]$.

Interestingly, growing evidence suggests that some psychotropic drugs could have beneficial effects on SARS$\mathrm{CoV}-2$ infection. Indeed, some studies suggest that haloperidol and chlorpromazine should be tested for COVID-19 [142, 143]. Among treatments used in suicidal behavior, antidepressants could have potential beneficial effects in patients with COVID-19 through their impact on the cytokine "storm." Antidepressants (i.e., tricyclic antidepressants and selective serotonin reuptake inhibitors) have anti-inflammatory properties by reducing pro-inflammatory cytokines, such as IL-6, IL1 , and interferon $\gamma$. Several in vitro and in vivo (animal models) studies and trials in humans have shown the antiinflammatory effect of these drugs at therapeutic concentrations [144-147]. Furthermore, SARS-CoV-2 could invade the CNS, because other coronaviruses (e.g., SARS-CoV and MERS-CoV) have been detected in the brain of victims and caused brain damage, notably due to inflammation [148, 149]. By passing through the BBB easily, antidepressants could reduce the inflammation induced in the brain by the virus. Moreover, some antidepressants inhibit microglial activation (a primordial vector of inflammation in the brain). For instance, it has been suggested that clomipramine is a potential treatment for multiple sclerosis due to its strong antiinflammatory effect in the brain [150-152]. Therefore, we

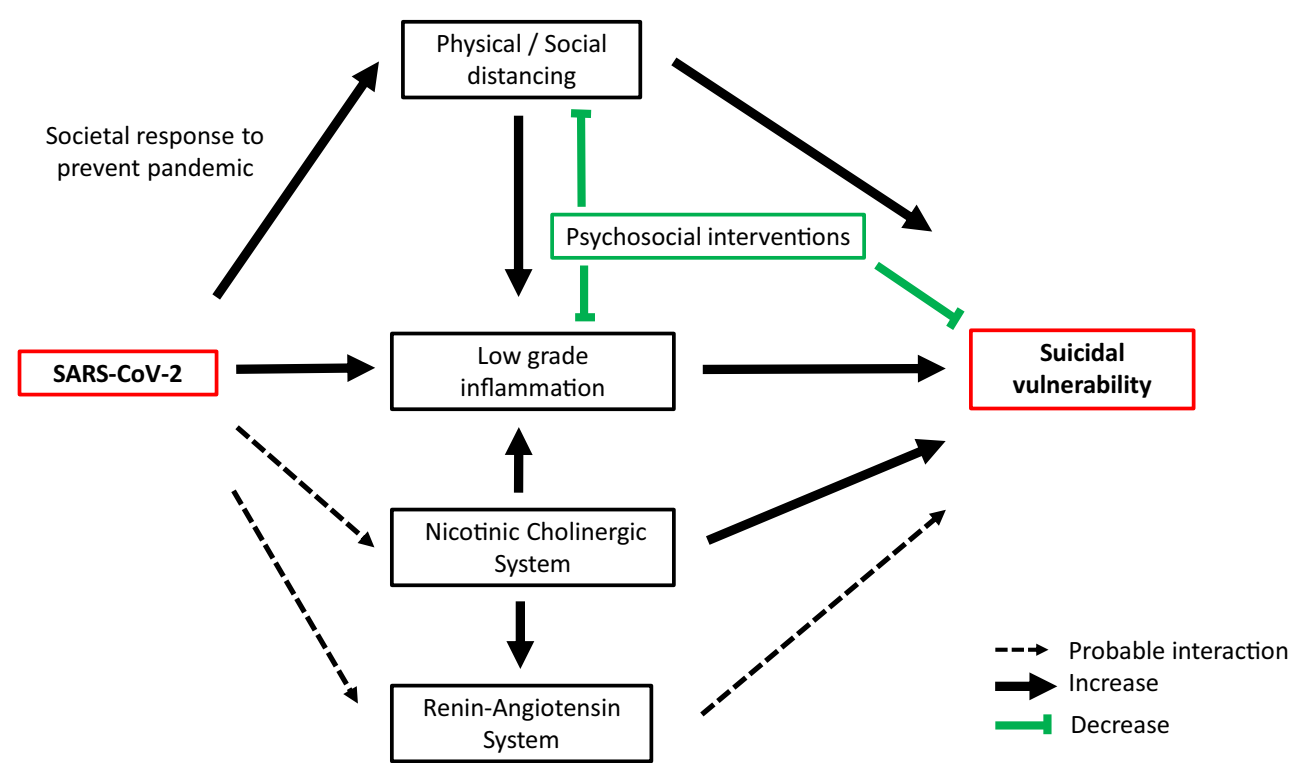

Fig. 1 Proposed model reporting the interaction between SRAS-CoV-2 and biological pathways underlying suicidal vulnerability. SARS-CoV-2 binds to ACE- 2 receptors that are expressed in the central nervous system and are a key component of the renin-angiotensin system involved in suicidal vulnerability. SARS-CoV-2 targets nicotinic receptors that are involved in the pathophysiology of mood disorders and suicidal behavior. SARS-CoV-2 induces the immune response, resulting in chronic lowgrade inflammation in peripheral organs and central nervous system,

which is associated with suicide. The nicotinic system regulates ACE/ ACE-2 expression and also the inflammatory response and may amplify COVID-19 effect on suicidal vulnerability. Social/physical distancing and feelings of social isolation may increase social pain, a key dimension leading to suicide and increasing low-grade inflammation. Psychosocial interventions may protect from suicide, attenuate social isolation, and modulate inflammatory processes. Black arrow: increase; green trait: decrease; dotted line: probable interaction 
could hypothesize that antidepressants may be useful for preventing SARS-CoV-2-linked CNS inflammation and consequently for preventing or reducing the risk of emergence or worsening of suicidal behavior.

\section{Conclusions and Research Perspectives}

Altogether, our narrative review highlights several possible interactions between COVID-19 and vulnerability to suicidal behavior. We propose a biological model (Fig. 1) to explain the higher suicidal vulnerability in individuals confronted with COVID-19 directly (virus infection) or indirectly (exposed to social distancing measures). Indeed, SARS-CoV-2 affects specific biological correlates of suicide: (i) it binds to ACE-2 receptors that are widely expressed in the CNS, are a key component of the renin-angiotensin system, and have been involved in suicidal vulnerability; (ii) SARS-CoV-2 targets nicotinic receptors that are involved in the pathophysiology of mood disorders and suicidal behavior; (iii) SARS-CoV-2 induces the immune response, resulting in chronic low-grade inflammation (peripheral organs and/or brain) that has been associated with suicide; (iv) the nicotinic system regulates ACE/ACE-2 expression and also the inflammatory response and may amplify COVID-19 effect on suicidal vulnerability; and (v) social distancing and feelings of social isolation may increase social pain, a key dimension leading to suicide. Interestingly, drugs used to manage suicidal patients might also prevent inflammation and protect from some of SARSCoV-2 deleterious effects in the CNS.

As suggested by Kim and $\mathrm{Su}$ (2020), it is time for immunopsychiatry services to address the biopsychosocial effects of the COVID-19 pandemic on another possible epidemic in the making: suicide [119]. Moreover, the COVID-19 outbreak and the complex biological processes underlying this infection offer new perspectives to better understand the multiple pathways leading to suicidal acts. The hypotheses described above need to be extensively tested. Longitudinal studies will help to determine the impact of chronic inflammation induced by COVID-19 on the frequency of suicidal acts in the mid(months) and long-term (years). COVID-19 is an opportunity for investigating the naturalistic association between psychiatric symptoms and viral respiratory infections. The naturalist observation of individuals with COVID-19, use of antidepressants, and hospital admissions/visits due to suicide attempts offer a unique opportunity to go from ecological to cohort studies, which are methodologically more powerful [153].

Furthermore, genetic studies should assess the existence of common genetic variants underlying the host's viral susceptibility and suicide vulnerability to better characterize the possible interactions between pathogen and suicidal behaviors. Ecosystem features influence SARS-CoV-2 infection, whereas suicidal behaviors are driven by the psychosocial environment. Hence, possible shared environmental risk factors may underlie infection and suicide risk within a population. It is important to take them into account in future research to disentangle specific viral/neural interactions from other confounding factors. Finally, psychosocial interventions might help to modulate the host's immune response. Their efficacy for preventing morbidity related to the infection should be assessed. Interestingly, research on treatments for COVID19 may benefit from studies on suicide because they might broaden the choice of anti-inflammatory and neuroprotective drugs. More research is required to evaluate the effectiveness of potential psycho-neuroimmunity preventive strategies to enhance resilience and prevent suicidal behavior [154]. Last, social and behavioral sciences and mental health sciences could help to align human behavior with the recommendations by epidemiologists and public health experts to fight the COVID-19 pandemic, while preventing the deleterious effects of such measures that may lead to a suicide epidemic. Would this help to build a "compassionate society and empathic civilization" [155] that might be more effective in preventing both epidemics? Probably, but much work remains to be done.

Funding This research did not receive any specific grant from funding agencies in the public, commercial, or not-for-profit sectors.

\section{References}

Papers of particular interest, published recently, have been highlighted as:

- Of importance

•• Of major importance

1. Johns Hopkins Coronavirus Resource Center [Internet]. Johns Hopkins Coronavirus Resour. Cent. [cited 2020 Apr 28]. Available from: https://coronavirus.jhu.edu/map.html

2. Lai J, Ma S, Wang Y, Cai Z, Hu J, Wei N, et al. Factors associated with mental health outcomes among health care workers exposed to coronavirus disease 2019. JAMA Netw Open American Medical Association. 2020;3:e203976-6.

3. Reynolds DL, Garay JR, Deamond SL, Moran MK, Gold W, Styra R. Understanding, compliance and psychological impact of the SARS quarantine experience. Epidemiol Infect. 2008;136: 997-1007.

4. Wu P, Liu X, Fang Y, Fan B, Fuller CJ, Guan Z, et al. Alcohol abuse/dependence symptoms among hospital employees exposed to a SARS outbreak. Alcohol Alcohol Oxf Oxfs. 2008;43:706-12.

5. Zhang J, Lu H, Zeng H, Zhang S, Du Q, Jiang T, Du B. The differential psychological distress of populations affected by the COVID-19 pandemic. Brain, Behavior, and Immunity. 2020;87: 49-50. https://doi.org/10.1016/j.bbi.2020.04.031.

6. Zhou J, Liu L, Xue P, Yang X, Tang X. Mental Health Response to the COVID-19 Outbreak in China. American Journal of Psychiatry. 2020;177(7):574-575. https://doi.org/10.1176/appi. ajp.2020.20030304.

7. Hao F, Tan W, Jiang L, Zhang L, Zhao X, Zou Y, et al. Do psychiatric patients experience more psychiatric symptoms during COVID-19 pandemic and lockdown? A case-control study with 
service and research implications for immunopsychiatry. Brain Behav Immun [Internet]. 2020; [cited 2020 May 18]; Available from: http://www.sciencedirect.com/science/article/pii/ S0889159120306267.

8. Yang Y, Li W, Zhang Q, Zhang L, Cheung T, Xiang Y-T. Mental health services for older adults in China during the COVID-19 outbreak. Lancet Psychiatry Elsevier. 2020;7:e19.

9. Calati R, Ferrari C, Brittner M, Oasi O, Olié E, Carvalho AF, et al. Suicidal thoughts and behaviors and social isolation: a narrative review of the literature. J Affect Disord. 2019;245:653-67.

10. van Gelder N, Peterman A, Potts A, O'Donnell M, Thompson K, Shah N, et al. COVID-19: reducing the risk of infection might increase the risk of intimate partner violence. EClinicalMedicine [Internet] Elsevier. 2020; [cited 2020 May 3];21. Available from: https://www.thelancet.com/journals/eclinm/article/PIIS25895370(20)30092-4/abstract.

11. McKee M, Stuckler D. If the world fails to protect the economy, COVID-19 will damage health not just now but also in the future. Nat Med Nature Publishing Group. 2020:1-3.

12. Kawohl W, Nordt C. COVID-19, unemployment, and suicide. Lancet Psychiatry Elsevier. 2020;7:389-90.

13. Wasserman IM. The impact of epidemic, war, prohibition and media on suicide: United States, 1910-1920. Suicide Life Threat Behav. 1992;22:240-54.

14. Troyer EA, Kohn JN, Hong S. Are we facing a crashing wave of neuropsychiatric sequelae of COVID-19? Neuropsychiatric symptoms and potential immunologic mechanisms. Brain Behav Immun [Internet]. 2020; [cited 2020 Apr 27]; Available from: http://www.sciencedirect.com/science/article/pii/ S088915912030489X.

15. Courtet P, Olié E. Social pain at the core of suicidal behavior. L'Encephale. 2019;45(Suppl 1):S7-12.

16. Okusaga O, Yolken RH, Langenberg P, Lapidus M, Arling TA, Dickerson FB, et al. Association of seropositivity for influenza and coronaviruses with history of mood disorders and suicide attempts. J Affect Disord. 2011;130:220-5.

17. Gjervig Hansen H, Köhler-Forsberg O, Petersen L, Nordentoft M, Postolache TT, Erlangsen A, et al. Infections, anti-infective agents, and risk of deliberate self-harm and suicide in a young cohort: a nationwide study. Biol Psychiatry. 2019;85:744-51.

18. Ducasse D, Olié E, Guillaume S, Artéro S, Courtet P. A metaanalysis of cytokines in suicidal behavior. Brain Behav Immun. 2015;46:203-11.

19.• Hommer R. Infections, anti-infective medications, and suicidal behavior: an association bearing further investigation. Biol Psychiatry Elsevier. 2019;85:711-2 This study shows the link between infections and suicidal behaviors.

20. Moriyama M, Hugentobler WJ, Iwasaki A. Seasonality of respiratory viral infections. Annu Rev Virol. 2020;7 null.

21. Woo J-M, Okusaga O, Postolache TT. Seasonality of suicidal behavior. Int J Environ Res Public Health. 2012;9:531-47.

22. Maes M, Scharpé S, D'Hondt P, Peeters D, Wauters A, Neels H, et al. Biochemical, metabolic and immune correlates of seasonal variation in violent suicide: a chronoepidemiologic study. Eur Psychiatry J Assoc Eur Psychiatr. 1996;11:21-33.

23. Marshall NB, Swain SL. Cytotoxic CD4 T cells in antiviral immunity. J Biomed Biotechnol. 2011;2011:954602.

24. Chen HD, Fraire AE, Joris I, Brehm MA, Welsh RM, Selin LK. Memory CD8 + T cells in heterologous antiviral immunity and immunopathology in the lung. Nat Immunol Nature Publishing Group. 2001;2:1067-76.

25. Chen G, Wu D, Guo W, Cao Y, Huang D, Wang H, et al. Clinical and immunological features of severe and moderate coronavirus disease 2019. J Clin Invest American Society for Clinical Investigation. 2020;130:2620-9.
26. Pape K, Tamouza R, Leboyer M, Zipp F. Immunoneuropsychiatry - novel perspectives on brain disorders. Nat Rev Neurol Nature Publishing Group. 2019;15:317-28.

27. Hoffmann M, Kleine-Weber H, Schroeder S, Krüger N, Herrler T, Erichsen S, et al. SARS-CoV-2 cell entry depends on ACE2 and TMPRSS2 and is blocked by a clinically proven protease inhibitor. Cell. 2020;181:271-280.e8.

28. Lan J, Ge J, Yu J, Shan S, Zhou H, Fan S, et al. Structure of the SARS-CoV-2 spike receptor-binding domain bound to the ACE2 receptor. Nature Nature Publishing Group. 2020:1-6.

29. Zheng Y-Y, Ma Y-T, Zhang J-Y, Xie X. COVID-19 and the cardiovascular system. Nat Rev Cardiol Nature Publishing Group. 2020;17:259-60.

30. Patel AB, Verma A. COVID-19 and angiotensin-converting enzyme inhibitors and angiotensin receptor blockers: what is the evidence? JAMA [Internet]. 2020; [cited 2020 May 5]; Available from: https://jamanetwork.com/journals/jama/ fullarticle/2763803.

31. Xia H, Lazartigues E. Angiotensin-converting enzyme 2 in the brain: properties and future directions. J Neurochem. 2008;107: 1482-94.

32. Fang L, Karakiulakis G, Roth M. Are patients with hypertension and diabetes mellitus at increased risk for COVID-19 infection? Lancet Respir Med Elsevier. 2020;8:e21

33. Rice GI, Thomas DA, Grant PJ, Turner AJ, Hooper NM. Evaluation of angiotensin-converting enzyme (ACE), its homologue ACE2 and neprilysin in angiotensin peptide metabolism. Biochem J. 2004;383:45-51.

34. Callréus T, Agerskov Andersen U, Hallas J, Andersen M. Cardiovascular drugs and the risk of suicide: a nested casecontrol study. Eur J Clin Pharmacol. 2007;63:591-6.

35. Callréus T, Agerskov Andersen U, Hallas J, Andersen M. Cardiovascular drugs and the risk of suicide: a nested case-control study. Eur J Clin Pharmacol. 2007;63:591-6.

36. Hishimoto A, Shirakawa O, Nishiguchi N, Hashimoto T, Yanagi $\mathrm{M}$, Nushida $\mathrm{H}$, et al. Association between a functional polymorphism in the renin-angiotensin system and completed suicide. J Neural Transm Vienna Austria 1996. 2006;113:1915-20.

37. Sparks DL, Hunsaker JC, Amouyel P, Malafosse A, Bellivier F, Leboyer M, et al. Angiotensin I-converting enzyme I/D polymorphism and suicidal behaviors. Am J Med Genet Part B Neuropsychiatr Genet Off Publ Int Soc Psychiatr Genet. 2009;150B:290-4.

38. Rigat B, Hubert C, Alhenc-Gelas F, Cambien F, Corvol P, Soubrier F. An insertion/deletion polymorphism in the angiotensin I-converting enzyme gene accounting for half the variance of serum enzyme levels. J Clin Invest. 1990;86:1343-6.

39. Baghai TC, Binder EB, Schule C, Salyakina D, Eser D, Lucae S, et al. Polymorphisms in the angiotensin-converting enzyme gene are associated with unipolar depression, ACE activity and hypercortisolism. Mol Psychiatry. 2006;11:1003-15.

40. Baghai TC, Schule C, Zwanzger P, Minov C, Zill P, Ella R, et al. Hypothalamic-pituitary-adrenocortical axis dysregulation in patients with major depression is influenced by the insertion/ deletion polymorphism in the angiotensin I-converting enzyme gene. Neurosci Lett. 2002;328:299-303.

41. Kucukali CI, Aydin M, Ozkok E, Bilge E, Zengin A, Cakir U, et al. Angiotensin-converting enzyme polymorphism in schizophrenia, bipolar disorders, and their first-degree relatives. Psychiatr Genet. 2010;20:14-9.

42. Ancelin ML, Carrière I, Scali J, Ritchie K, Chaudieu I, Ryan J. Angiotensin-converting enzyme gene variants are associated with both cortisol secretion and late-life depression. Transl Psychiatry. 2013;3:e322. 
43. Steardo L, Steardo L, Zorec R, Verkhratsky A. Neuroinfection may contribute to pathophysiology and clinical manifestations of COVID-19. Acta Physiol. n.d.) n/a:e13473.

44. Mao X-Y, Jin W-L. The COVID-19 pandemic: consideration for brain infection. Neuroscience [Internet]. 2020; [cited 2020 May 11]; Available from: https://www.ncbi.nlm.nih.gov/pmc/ articles/PMC7196901/.

45. Magrone T, Magrone M, Jirillo E. Focus on receptors for coronaviruses with special reference to angiotensin-converting enzyme 2 as a potential drug target - a perspective. Endocr Metab Immune Disord Drug Targets. 2020;20:807-11.

46. Nataf S. An alteration of the dopamine synthetic pathway is possibly involved in the pathophysiology of COVID-19. J Med Virol [Internet]. n.d.; [cited 2020 May 8];n/a. Available from: https:// onlinelibrary.wiley.com/doi/abs/10.1002/jmv.25826.

47. Oakes JM, Fuchs RM, Gardner JD, Lazartigues E, Yue X. Nicotine and the renin-angiotensin system. Am J Phys Regul Integr Comp Phys. 2018;315:R895-906.

48. Malone KM, Waternaux C, Haas GL, Cooper TB, Li S, Mann JJ. Cigarette smoking, suicidal behavior, and serotonin function in major psychiatric disorders. Am J Psychiatry American Psychiatric Publishing. 2003;160:773-9.

49. Poorolajal J, Darvishi N. Smoking and suicide: a meta-analysis. PLoS One. 2016;11:e0156348.

50. Benwell ME, Balfour DJ, Anderson JM. Smoking-associated changes in the serotonergic systems of discrete regions of human brain. Psychopharmacology. 1990;102:68-72.

51. Schwartz RD, Lehmann J, Kellar KJ. Presynaptic nicotinic cholinergic receptors labeled by $[3 \mathrm{H}]$ acetylcholine on catecholamine and serotonin axons in brain. J Neurochem. 1984;42:1495-8.

52. Olausson P, Engel JA, Söderpalm B. Involvement of serotonin in nicotine dependence: processes relevant to positive and negative regulation of drug intake. Pharmacol Biochem Behav. 2002;71: 757-71.

53. Mineur YS, Picciotto MR. Nicotine receptors and depression: revisiting and revising the cholinergic hypothesis. Trends Pharmacol Sci. 2010;31:580-6.

54. Farsalinos K, Niaura R, Le Houezec J, Barbouni A, Tsatsakis A, Kouretas D, et al. Editorial: nicotine and SARS-CoV-2: COVID19 may be a disease of the nicotinic cholinergic system. Toxicol Rep [Internet]. 2020; [cited 2020 May 19]; Available from: https:// www.ncbi.nlm.nih.gov/pmc/articles/PMC7192087/.

55. Patanavanich R, Glantz SA. Smoking is associated with COVID19 progression: a meta-analysis. medRxiv. Cold Spring Harbor Laboratory Press. 2020;2020(04):13.20063669.

56. Changeux J-P, Amoura Z, Rey F, Miyara M. A nicotinic hypothesis for Covid-19 with preventive and therapeutic implications. Qeios [Internet]. 2020; [cited 2020 May 6]; Available from: https://www.qeios.com/read/FXGQSB.

57. Leung JM, Yang CX, Tam A, Shaipanich T, Hackett T-L, Singhera GK, et al. ACE-2 Expression in the small airway epithelia of smokers and COPD patients: implications for COVID-19. Eur Respir J [Internet]. 2020; [cited 2020 May 18]; Available from: https:/www.ncbi.nlm.nih.gov/pmc/articles/PMC7144263/.

58. Ferrari MFR, Raizada MK, Fior-Chadi DR. Nicotine modulates the renin-angiotensin system of cultured neurons and glial cells from cardiovascular brain areas of Wistar Kyoto and spontaneously hypertensive rats. J Mol Neurosci. 2007;33:284-93.

59. Ferrari MFR, Raizada MK, Fior-Chadi DR. Differential regulation of the renin-angiotensin system by nicotine in WKY and SHR glia. J Mol Neurosci. 2008;35:151-60.

60. Wang H, Yu M, Ochani M, Amella CA, Tanovic M, Susarla S, et al. Nicotinic acetylcholine receptor $\alpha 7$ subunit is an essential regulator of inflammation. Nature Nature Publishing Group. $2003 ; 421: 384-8$.
61. Slavich GM, Irwin MR. From stress to inflammation and major depressive disorder: a social signal transduction theory of depression. Psychol Bull. 2014;140:774-815.

62. Courtet P, Giner L, Seneque M, Guillaume S, Olie E, Ducasse D. Neuroinflammation in suicide: toward a comprehensive model. World J Biol Psychiatry. 2016;17:564-86.

63. Mehta P, McAuley DF, Brown M, Sanchez E, Tattersall RS, Manson JJ. COVID-19: consider cytokine storm syndromes and immunosuppression. Lancet Elsevier. 2020;395:1033-4.

64. Shi Y, Wang Y, Shao C, Huang J, Gan J, Huang X, et al. COVID19 infection: the perspectives on immune responses. Cell Death Differ Nature Publishing Group. 2020;27:1451-4.

65. Moore JB, June CH. Cytokine release syndrome in severe COVID-19. Science American Association for the Advancement of Science. 2020;368:473-4.

66. De Felice FG, Tovar-Moll F, Moll J, Munoz DP, Ferreira ST. Severe acute respiratory syndrome coronavirus 2 (SARS-CoV-2) and the central nervous system. Trends Neurosci [Internet]. 2020; [cited 2020 May 6]; Available from: http://www.sciencedirect. com/science/article/pii/S0166223620300916.

67. Conejero I, Jaussent I, Cazals A, Thouvenot E, Mura T, Le Bars E, et al. Association between baseline pro-inflammatory cytokines and brain activation during social exclusion in patients with vulnerability to suicide and depressive disorder. Psychoneuroendocrinology. 2019;99:236-42.

68. Lengvenyte A, Conejero I, Courtet P, Olié E. Biological bases of suicidal behaviours: a narrative review. Eur J Neurosci [Internet]. [cited 2020 May 3];n/a. Available from: https://onlinelibrary. wiley.com/doi/abs/10.1111/ejn.14635

69. Courtet P, Jaussent I, Genty C, Dupuy AM, Guillaume S, Ducasse $\mathrm{D}$, et al. Increased CRP levels may be a trait marker of suicidal attempt. Eur Neuropsychopharmacol J Eur Coll Neuropsychopharmacol. 2015;25:1824-31.

70. Chang C-C, Tzeng N-S, Kao Y-C, Yeh C-B, Chang H-A. The relationships of current suicidal ideation with inflammatory markers and heart rate variability in unmedicated patients with major depressive disorder. Psychiatry Res. 2017;258:449-56.

71. Black C, Miller BJ. Meta-analysis of cytokines and chemokines in suicidality: distinguishing suicidal versus nonsuicidal patients. Biol Psychiatry. 2015;78:28-37.

72. Aziz M, Fatima R, Assaly R. Elevated interleukin-6 and severe COVID-19: a meta-analysis. J Med Virol [Internet]. [cited 2020 May 11];n/a. Available from: https://onlinelibrary.wiley.com/doi/ abs/10.1002/jmv. 25948

73. Isung J, Aeinehband S, Mobarrez F, Nordström P, Runeson B, Åsberg M, et al. High interleukin-6 and impulsivity: determining the role of endophenotypes in attempted suicide. Transl Psychiatry Nature Publishing Group. 2014;4:e470-0.

74. Ting EY-C, Yang AC, Tsai S-J. Role of interleukin-6 in depressive disorder. Int J Mol Sci [Internet]. 2020; [cited 2020 May 6];21. Available from: https://www.ncbi.nlm.nih.gov/pmc/ articles/PMC7139933/.

75. Nässberger L, Träskman-Bendz L. Increased soluble interleukin-2 receptor concentrations in suicide attempters. Acta Psychiatr Scand. 1993;88:48-52.

76. Yilla M, Harcourt BH, Hickman CJ, McGrew M, Tamin A, Goldsmith CS, et al. SARS-coronavirus replication in human peripheral monocytes/macrophages. Virus Res. 2005;107:93-101.

77. Zhou Y, Fu B, Zheng X, Wang D, Zhao C, Qi Y, et al. Pathogenic $\mathrm{T}$ cells and inflammatory monocytes incite inflammatory storm in severe COVID-19 patients. Natl Sci Rev [Internet]. 2020; [cited 2020 May 18]; Available from: https:/www.ncbi.nlm.nih.gov/ pmc/articles/PMC7108005/.

78. Savitz J, Harrison NA. Interoception and inflammation in psychiatric disorders. Biol Psychiatry Cogn Neurosci Neuroimaging. 2018;3:514-24. 
79.• Holmes SE, Hinz R, Conen S, Gregory CJ, Matthews JC, AntonRodriguez JM, et al. Elevated translocator protein in anterior cingulate in major depression and a role for inflammation in suicidal thinking: a positron emission tomography study. Biol Psychiatry. 2018;83:61-9.

80. Velasco Á, Rodríguez-Revuelta J, Olié E, Abad I, FernándezPeláez A, Cazals A, et al. Neutrophil-to-lymphocyte ratio: a potential new peripheral biomarker of suicidal behavior. Eur Psychiatry J Assoc Eur Psychiatr. 2020;63:e14.

81. Nowak W, Grendas LN, Sanmarco LM, Estecho IG, Arena ÁR, Eberhardt N, et al. Pro-inflammatory monocyte profile in patients with major depressive disorder and suicide behaviour and how ketamine induces anti-inflammatory M2 macrophages by NMDAR and mTOR. EBioMedicine. 2019;50:290-305.

82. Keaton SA, Madaj ZB, Heilman P, Smart L, Grit J, Gibbons R, et al. An inflammatory profile linked to increased suicide risk. J Affect Disord. 2019;247:57-65.

83. Chen M-H, Li C-T, Lin W-C, Hong C-J, Tu P-C, Bai Y-M, et al. Rapid inflammation modulation and antidepressant efficacy of a low-dose ketamine infusion in treatment-resistant depression: a randomized, double-blind control study. Psychiatry Res. 2018;269:207-11.

84. Pal R. COVID-19, hypothalamo-pituitary-adrenal axis and clinical implications. Endocrine. 2020;68:251-2.

85. Wheatland R. Molecular mimicry of ACTH in SARS - implications for corticosteroid treatment and prophylaxis. Med Hypotheses. 2004;63:855-62.

86. Leow MK-S, Kwek DS-K, Ng AW-K, Ong K-C, Kaw GJ-L, Lee LS-U. Hypocortisolism in survivors of severe acute respiratory syndrome (SARS). Clin Endocrinol. 2005;63:197-202.

87. Lindqvist D, Isaksson A, Lil-Träskman-Bendz, Brundin L. Salivary cortisol and suicidal behavior-a follow-up study. Psychoneuroendocrinology. 2008;33:1061-1068.

88. Melhem NM, Keilp JG, Porta G, Oquendo MA, Burke A, Stanley B, et al. Blunted HPA axis activity in suicide attempters compared to those at high risk for suicidal behavior. Neuropsychopharmacology. 2016;41:1447-56

89. Alacreu-Crespo A, Olié E, Guillaume S, Girod C, Cazals A, Chaudieu I, et al. Dexamethasone suppression test may predict more severe/violent suicidal behavior. Front Psychiatry. 2020;11:97.

90. Rabelo I, Lee V, Fallah MP, Massaquoi M, Evlampidou I, Crestani R, et al. Psychological distress among Ebola survivors discharged from an Ebola Treatment Unit in Monrovia, Liberia - a qualitative study. Front Public Health [Internet] Frontiers. 2016; [cited 2020 May 3];4. Available from: https://www.frontiersin. org/articles/10.3389/fpubh.2016.00142/full.

91. Cacioppo JT, Cacioppo S, Capitanio JP, Cole SW. The neuroendocrinology of social isolation. Annu Rev Psychol. 2015;66:733-67.

92. Slavich GM, O’Donovan A, Epel ES, Kemeny ME. Black sheep get the blues: a psychobiological model of social rejection and depression. Neurosci Biobehav Rev. 2010;35:39-45.

93. Marchand WR, Lee JN, Johnson S, Gale P, Thatcher J. Abnormal functional connectivity of the medial cortex in euthymic bipolar II disorder. Prog Neuro-Psychopharmacol Biol Psychiatry. 2014;51: 28-33.

94. Liu H, Wang Y, Liu W, Wei D, Yang J, Du X, et al. Neuroanatomical correlates of attitudes toward suicide in a large healthy sample: a voxel-based morphometric analysis. Neuropsychologia. 2016;80:185-93.

95. Bani-Fatemi A, Tasmim S, Graff-Guerrero A, Gerretsen P, Strauss J, Kolla N, et al. Structural and functional alterations of the suicidal brain: an updated review of neuroimaging studies. Psychiatry Res Neuroimaging. 2018;278:77-91.
96. Wang H, Braun C, Enck P. How the brain reacts to social stress (exclusion) - a scoping review. Neurosci Biobehav Rev. 2017;80: $80-8$.

97.• Olié E, Jollant F, Deverdun J, de Champfleur NM, Cyprien F, Le Bars E, et al. The experience of social exclusion in women with a history of suicidal acts: a neuroimaging study. Sci Rep [Internet]. 2017:7 [cited 2017 Aug 8]. Available from: http://www.nature. com/articles/s41598-017-00211-x This neuroimaging study emphasizes the neural correlates of social exclusion in patients with suicidal vulnerability.

98. Usher K, Bhullar N, Jackson D. Life in the pandemic: social isolation and mental health. J Clin Nurs [Internet]. [cited 2020 May 3];n/a. Available from: https://onlinelibrary.wiley.com/doi/ abs/10.1111/jocn.15290

99. Bavel JJV, Baicker K, Boggio PS, Capraro V, Cichocka A, Cikara $\mathrm{M}$, et al. Using social and behavioural science to support COVID19 pandemic response. Nat Hum Behav Nature Publishing Group. 2020;4:460-71.

100. Foster T. Adverse life events proximal to adult suicide: a synthesis of findings from psychological autopsy studies. Arch Suicide Res Off J Int Acad Suicide Res. 2011;15:1-15.

101. Courtet P, Guillaume S, Malafosse A, Jollant F. Genes, suicide and decisions. Eur Psychiatry. 2010;25:294-6.

102. Norman RE, Byambaa M, De R, Butchart A, Scott J, Vos T. The long-term health consequences of child physical abuse, emotional abuse, and neglect: a systematic review and meta-analysis. PLoS Med. 2012;9:e1001349.

103. McCrory EJ, Viding E. The theory of latent vulnerability: reconceptualizing the link between childhood maltreatment and psychiatric disorder. Dev Psychopathol Cambridge University Press. 2015;27:493-505.

104. Turecki G, Ernst C, Jollant F, Labonté B, Mechawar N. The neurodevelopmental origins of suicidal behavior. Trends Neurosci. 2012;35:14-23.

105. Claassen CA, Carmody T, Stewart SM, Bossarte RM, Larkin GL, Woodward WA, et al. Effect of 11 September 2001 terrorist attacks in the USA on suicide in areas surrounding the crash sites. Br J Psychiatry Cambridge University Press. 2010;196:359-64.

106. Misiak B, Szcześniak D, Kaczanowicz L, Rymaszewska J. The COVID-19 outbreak and Google searches: is it really the time to worry about global mental health? Brain Behav Immun [Internet]. 2020; [cited 2020 May 11]; Available from: https://www.ncbi. nlm.nih.gov/pmc/articles/PMC7189861/.

107. Ducasse D, Jaussent I, Arpon-Brand V, Vienot M, Laglaoui C, Béziat S, et al. Acceptance and commitment therapy for the management of suicidal patients: a randomized controlled trial. Psychother Psychosom. 2018;87:211-22.

108. Alacreu-Crespo A, Cazals A, Courtet P, Olié E. Brief assessment of psychological pain to predict suicidal events at one year in depressed patients. Psychother Psychosom. 2020:1-4.

109. Eisenberger NI, Moieni M, Inagaki TK, Muscatell KA, Irwin MR. In sickness and in health: the co-regulation of inflammation and social behavior. Neuropsychopharmacol Off Publ Am Coll Neuropsychopharmacol. 2017;42:242-53.

110.• Miller AH, Raison CL. The role of inflammation in depression: from evolutionary imperative to modern treatment target. Nat Rev Immunol. 2015;16:22-34 This review highlights the role of peripheral inflammation in affective disorders and especially in depressive disorders.

111. Andrade C. Ketamine for depression, 6: effects on suicidal ideation and possible use as crisis intervention in patients at suicide risk. J Clin Psychiatry. 2018;79:18f12242.

112. Lutz P-E, Courtet P, Calati R. The opioid system and the social brain: implications for depression and suicide. J Neurosci Res. 2020;98:588-600. 
113. Bershad AK, Jaffe JH, Childs E, de Wit H. Opioid partial agonist buprenorphine dampens responses to psychosocial stress in humans. Psychoneuroendocrinology. 2015;52:281-8.

114.• Yovell Y, Bar G, Mashiah M, Baruch Y, Briskman I, Asherov J, et al. Ultra-low-dose buprenorphine as a time-limited treatment for severe suicidal ideation: a randomized controlled trial. Am J Psychiatry. 2015;173:491-8 This study shows the efficacy of pain treatments on psychological pain and suicidal ideation.

115. Simpson RJ, Katsanis E. The immunological case for staying active during the COVID-19 pandemic. Brain Behav Immun [Internet]. 2020; [cited 2020 May 18]; Available from: https:// www.ncbi.nlm.nih.gov/pmc/articles/PMC7165095/.

116. Courtet P, Olié E, Debien C, Vaiva G. Keep socially (but not physically) connected and carry on: preventing suicide in the age of COVID-19. J Clin Psychiatry. 2020;81.

117. Williams WC, Morelli SA, Ong DC, Zaki J. Interpersonal emotion regulation: implications for affiliation, perceived support, relationships, and well-being. J Pers Soc Psychol. 2018;115:224-54.

118. Doré BP, Morris RR, Burr DA, Picard RW, Ochsner KN. Helping others regulate emotion predicts increased regulation of one's own emotions and decreased symptoms of depression. Personal Soc Psychol Bull. 2017;43:729-39.

119. Kim S-W, Su K-P. Using psychoneuroimmunity against COVID19. Brain Behav Immun. 2020;87:4-5.

120. Breines JG, Thoma MV, Gianferante D, Hanlin L, Chen X, Rohleder N. Self-compassion as a predictor of interleukin-6 response to acute psychosocial stress. Brain Behav Immun. 2014;37:109-14.

121. Ducasse D, Dassa D, Courtet P, Brand-Arpon V, Walter A, Guillaume S, et al. Gratitude diary for the management of suicidal inpatients: a randomized controlled trial. Depress Anxiety. 2019;36:400-11.

122. Hartanto A, STH L, Yong JC. Dispositional gratitude moderates the association between socioeconomic status and interleukin-6. Sci Rep Nature Publishing Group. 2019;9:802.

123.• Brooks SK, Webster RK, Smith LE, Woodland L, Wessely S, Greenberg N, et al. The psychological impact of quarantine and how to reduce it: rapid review of the evidence. Lancet. 2020;395: 912-20 This review reports extensively the mental consequences of quarantine during recent pandemics.

124. Neergheen VL, Topel M, Van Dyke ME, Sullivan S, Pemu PE, Gibbons GH, et al. Neighborhood social cohesion is associated with lower levels of interleukin-6 in African American women. Brain Behav Immun. 2019;76:28-36.

125. Jakovljevic M. COVID-19 crisis as a collective Hero's journey to better public and global mental health. Psychiatr Danub. 2020;32: 3-5.

126. Eisenberger NI, Cole SW. Social neuroscience and health: neurophysiological mechanisms linking social ties with physical health. Nat Neurosci Nature Publishing Group. 2012;15:669-74.

127. Vaiva G, Berrouiguet S, Walter M, Courtet P, Ducrocq F, Jardon $\mathrm{V}$, et al. Combining postcards, crisis cards, and telephone contact into a decision-making algorithm to reduce suicide reattempt: a randomized clinical trial of a personalized brief contact intervention. J Clin Psychiatry. 2018;79.

128. Briffault X, Morgiève M, Courtet P. From e-Health to i-Health: prospective reflexions on the use of intelligent systems in mental health care. Brain Sci [Internet]. 2018; [cited 2020 May 11];8. Available from: https://www.ncbi.nlm.nih.gov/pmc/articles/ PMC6025161/.

129. Larsen ME, Shand F, Morley K, Batterham PJ, Petrie K, Reda B, et al. A mobile text message intervention to reduce repeat suicidal episodes: design and development of reconnecting after a suicide attempt (RAFT). JMIR Ment Health. 2017;4:e56.

130. Montero-Marin J, Andrés-Rodríguez L, Tops M, Luciano JV, Navarro-Gil M, Feliu-Soler A, et al. Effects of attachment-based compassion therapy $(\mathrm{ABCT})$ on brain-derived neurotrophic factor and low-grade inflammation among fibromyalgia patients: a randomized controlled trial. Sci Rep Nat Publ Group. 2019;9:15639.

131. Kasahara-Kiritani M, Hadlaczky G, Westerlund M, Carli V, Wasserman C, Apter A, et al. Reading books and watching films as a protective factor against suicidal ideation. Int $\mathrm{J}$ Environ Res Public Health. 2015;12:15937-42.

132. Conrad C, Niess H, Jauch KW, Bruns CJ, Hartl W, Welker L. Overture for growth hormone: requiem for interleukin-6? Crit Care Med. 2007.

133. Klomek AB. Suicide prevention during the COVID-19 outbreak. Lancet Psychiatry Elsevier. 2020;7:390.

134. Monteith LL, Holliday R, Brown TL, Brenner LA, Mohatt NV. Preventing suicide in rural communities during the COVID-19 pandemic. J Rural Health [Internet]. [cited 2020 Apr 27];n/a. Available from: https://onlinelibrary.wiley.com/doi/abs/10.1111/ jrh. 12448

135. Lu Y, Ho CS, Liu X, Chua AN, Wang W, McIntyre RS, et al. Chronic administration of fluoxetine and pro-inflammatory cytokine change in a rat model of depression. PLoS ONE [Internet]. 2017 [cited 2020 May 18];12. Available from: https://www.ncbi. nlm.nih.gov/pmc/articles/PMC5648231/

136. Zalsman G, Hawton K, Wasserman D, van Heeringen K, Arensman E, Sarchiapone M, et al. Suicide prevention strategies revisited: 10-year systematic review. Lancet Psychiatry. 2016;3: 646-59.

137. Courtet P, Olié É. Antidepressants do prevent suicide, at least pending something better. Bull Acad Natl Méd. 2014;198:88192.

138. Javelot H, Llorca P-M, Drapier D, Fakra E, Hingray C, Meyer G, et al. Informations relatives aux psychotropes et à leurs adaptations éventuelles pour les patients souffrant de troubles psychiques en France pendant l'épidémie à SARS-CoV-2. L'Encéphale [Internet]. 2020; [cited 2020 May 7]; Available from: https:// linkinghub.elsevier.com/retrieve/pii/S0013700620300749.

139. Luykx JJ, van Veen SMP, Risselada A, Naarding P, Tijdink JK, Vinkers C. Safe and informed prescribing of psychotropic medication during the COVID-19 pandemic. Br J Psychiatry. 2020:1-9.

140. Siskind D, Honer WG, Clark S, Correll CU, Hasan A, Howes O, et al. Consensus statement on the use of clozapine during the COVID-19 pandemic. J Psychiatry Neurosci. 2020;45:222-3.

141. Practice guideline for the assessment and treatment of patients with suicidal behaviors. Am J Psychiatry. 2003;160:1-60.

142. Gordon DE, Jang GM, Bouhaddou M, Xu J, Obernier K, O’Meara MJ, et al. A SARS-CoV-2-human protein-protein interaction map reveals drug targets and potential drug-repurposing [internet]. Syst Biol. 2020; Available from: http://biorxiv.org/lookup/doi/10. 1101/2020.03.22.002386.

143. Plaze M, Attali D, Petit A-C, Blatzer M, Simon-Loriere E, Vinckier F, et al. Repositionnement de la chlorpromazine dans le traitement du COVID-19: étude reCoVery. L'Encéphale [Internet]. 2020; [cited 2020 May 7]; Available from: https:// linkinghub.elsevier.com/retrieve/pii/S0013700620300798.

144. Baumeister D, Ciufolini S, Mondelli V. Effects of psychotropic drugs on inflammation: consequence or mediator of therapeutic effects in psychiatric treatment? Psychopharmacology. 2016;233: 1575-89.

145. Hiles SA, Baker AL, de Malmanche T, Attia J. Interleukin-6, Creactive protein and interleukin-10 after antidepressant treatment in people with depression: a meta-analysis. Psychol Med. 2012;42:2015-26.

146. Carvalho LA, Garner BA, Dew T, Fazakerley H, Pariante CM. Antidepressants, but not antipsychotics, modulate GR function in human whole blood: an insight into molecular mechanisms. Eur Neuropsychopharmacol. 2010;20:379-87. 
147. Diamond M, Kelly JP, Connor TJ. Antidepressants suppress production of the Th1 cytokine interferon- $\gamma$, independent of monoamine transporter blockade. Eur Neuropsychopharmacol. 2006;16:481-90.

148. Wu Y, Xu X, Chen Z, Duan J, Hashimoto K, Yang L, et al. Nervous system involvement after infection with COVID-19 and other coronaviruses. Brain Behav Immun [Internet]. 2020; [cited 2020 May 7]; Available from: https://linkinghub.elsevier.com/ retrieve/pii/S0889159120303573.

149. Natoli S, Oliveira V, Calabresi P, Maia LF, Pisani A. Does SARSCov-2 invade the brain? Translational lessons from animal models. Eur J Neurol [Internet]. 2020; [cited 2020 May 7]; Available from: https://onlinelibrary.wiley.com/doi/abs/10.1111/ ene.14277.

150. Hwang J, Zheng LT, Ock J, Lee MG, Kim S-H, Lee H-W, et al. Inhibition of glial inflammatory activation and neurotoxicity by tricyclic antidepressants. Neuropharmacology. 2008;55:826-34.

151. Gong W, Zhang S, Zong Y, Halim M, Ren Z, Wang Y, et al. Involvement of the microglial NLRP3 inflammasome in the antiinflammatory effect of the antidepressant clomipramine. J Affect Disord. 2019;254:15-25.

152. Faissner S, Mishra M, Kaushik DK, Wang J, Fan Y, Silva C, et al. Systematic screening of generic drugs for progressive multiple sclerosis identifies clomipramine as a promising therapeutic. Nat Commun [Internet]. 2017; [cited 2020 May 7];8. Available from: http://www.nature.com/articles/s41467-017-02119-6.

153. Brietzke E, Magee T, Freire RCR, Gomes FA, Milev R. Three insights on psychoneuroimmunology of mood disorders to be taken from the COVID-19 pandemic. Brain Behav Immun Health [Internet]. 2020; [cited 2020 May 18]; Available from: https:// www.ncbi.nlm.nih.gov/pme/articles/PMC7174985/.

154. Ho CS, Chee CY, Ho RC. Mental health strategies to combat the psychological impact of COVID-19 beyond paranoia and panic. Ann Acad Med Singap. 2020;49:155-60.

155. Jakovljevic M, Bjedov S, Jaksic N, Jakovljevic I. COVID-19 pandemia and public and global mental health from the perspective of global health securit. Psychiatr Danub. 2020;32:6-14.

156. Zhang J, Xie B, Hashimoto K. Current status of potential therapeutic candidates for the COVID-19 crisis. Brain Behav Immun [Internet]. 2020; [cited 2020 May 9]; Available from: https:// linkinghub.elsevier.com/retrieve/pii/S0889159120305894.

157. Lythgoe MP, Middleton P. Ongoing clinical trials for the management of the COVID-19 pandemic. Trends Pharmacol Sci [Internet]. 2020; [cited 2020 May 9]; Available from: https:// linkinghub.elsevier.com/retrieve/pii/S0165614720300705.

158. Sato K, Mano T, Iwata A, Toda T. Neuropsychiatric adverse events of chloroquine: a real-world pharmacovigilance study using the FDA Adverse Event Reporting System (FAERS) database. Biosci Trends [Internet]. 2020; [cited 2020 May 9]; Available from: https://www.jstage.jst.go.jp/article/bst/advpub/0/ advpub_2020.03082/_article.

159. Pinho de Oliveira Ribeiro N, Rafael de Mello Schier A, Ornelas AC, Pinho de Oliveira CM, Nardi AE, Silva AC. Anxiety, depression and suicidal ideation in patients with rheumatoid arthritis in use of methotrexate, hydroxychloroquine, leflunomide and biological drugs. Compr Psychiatry. 2013;54:1185-9.

160. Williams DW, Li Y, Dastgheyb R, Fitzgerald KC, Maki PM, Spence AB, et al. Associations between antiretroviral drugs on depressive symptomatology in homogenous subgroups of women with HIV. J Neuroimmune Pharmacol [Internet]. 2020; [cited 2020 May 9]; Available from: http://link.springer.com/10.1007/ s11481-019-09899-2.

161. Starace F, Bartoli L, Aloisi MS, Antinori A, Narciso P, Ippolito G, et al. Cognitive and affective disorders associated to HIV infection in the HAART era: findings from the NeuroICONA study cognitive impairment and depression in HIV/AIDS. The NeuroICONA study. Acta Psychiatr Scand. 2002;106:20-6.

162. Gutiérrez F, García L, Padilla S, Álvarez D, Moreno S, Navarro G, et al. Risk of clinically significant depression in HIV-infected patients: effect of antiretroviral drugs: depression in HIVinfected patients. HIV Med. 2014;15:213-23.

163. Low-Beer S, Chan K, Yip B, Wood E, Montaner JSG, O'Shaughnessy MV, et al. Depressive symptoms decline among persons on HIV protease inhibitors. JAIDS J Acquir Immune Defic Syndr. 2000;23:295-301.

164. Tarasov VV, Kudryashov NV, Chubarev VN, Kalinina TS, Barreto GE, Ashraf GM, et al. Pharmacological aspects of neuro-immune interactions. Curr Pharm Des. 2018;24:15-21.

165. Chung S, Joung YS. Oseltamivir (Tamiflu) induced depressive episode in a female adolescent. Psychiatry Investig. 2010;7:302-4.

166. Dutkowski R, Thakrar B, Froehlich E, Suter P, Oo C, Ward P. Safety and pharmacology of oseltamivir in clinical use. Drug Saf. 2003;26:787-801.

167. Sockalingam S, Links PS, Abbey SE. Suicide risk in hepatitis C and during interferon-alpha therapy: a review and clinical update: suicide risk in hepatitis C. J Viral Hepat. 2011;18:153-60.

168. Lucaciu LA, Dumitrascu DL. Depression and suicide ideation in chronic hepatitis $\mathrm{C}$ patients untreated and treated with interferon: prevalence, prevention, and treatment. Ann Gastroenterol. 2015;28:440-7.

169. Choy EHS, Calabrese LH. Neuroendocrine and neurophysiological effects of interleukin 6 in rheumatoid arthritis. Rheumatology. 2018;57:1885-95.

170. Khandaker GM, Oltean BP, Kaser M, Dibben CRM, Ramana R, Jadon DR, et al. Protocol for the insight study: a randomised controlled trial of single-dose tocilizumab in patients with depression and low-grade inflammation. BMJ Open. 2018;8:e25333.

171. Kappelmann N, Lewis G, Dantzer R, Jones PB, Khandaker GM. Antidepressant activity of anti-cytokine treatment: a systematic review and meta-analysis of clinical trials of chronic inflammatory conditions. Mol Psychiatry. 2018;23:335-43.

172. Koo JW, Duman RS. Evidence for IL-1 receptor blockade as a therapeutic strategy for the treatment of depression. Curr Opin Investig Drugs Lond Engl 2000. 2009;10:664-71.

173. Carle G, Abgrall-Barbry G. Conduites suicidaires et corticothérapie: à propos d'un cas. L'Encéphale. 2016;42:272-6.

174. Cornic F, Rousset I. Glucocorticoids induced neuropsychiatric disorders. Rev Prat. 2008;58:469-75.

175. Vanelle JM, Aubin F, Michel F. Psychiatric complications of corticotherapy. Rev Prat. 1990;40:556-8.

Publisher's Note Springer Nature remains neutral with regard to jurisdictional claims in published maps and institutional affiliations. 